\title{
Pengaruh Strategi Diversifikasi Terhadap Kinerja Perusahaan Pada Perusahaan Food And Beverages
}

\author{
DEWI SRI ${ }^{1}$; MING $\mathrm{CHEN}^{2}$ \\ ${ }^{1,2}$ Universitas Katolik Musi Charitas \\ Jalan Bangau No.60 Palembang \\ Email: dewi_sri@ukmc.ac.id
}

\begin{abstract}
The purpose of this study was to empirically examine whether the diversification strategy had an effect on company performance in Food And Beverages companies listed on the Indonesia Stock Exchange in 2014 - 2017. In this study the diversification strategy variable was proxied by Hierschman Herfindah Index (HHI). Company performance is measured by Economic Value Added (EVA). The sample of this research is Food And Beverages companies listed on the Indonesia Stock Exchange from 2014 to 2017. This study uses a simple regression model and uses SPSS as a testing tool. The results showed that the hypothesis was rejected so that it showed that the diversified strategy variables did not affect the financial performance of Food and Beverages companies.
\end{abstract}

Keywords: Diversification Strategy, Company Performance

Saat ini perekonomian dunia mengalami perkembangan yang sangat pesat, hal ini membuat semua negara yang ada di dunia melakukan inovasi agar dapat bersaing dengan negara lain. Indonesia merupakan negara yang juga mengalami perkembangan yang pesat karena Indonesia masuk dalam kawasan Asia Tenggara (ASEAN) yang mulai berintergrasi untuk meningkatkan daya saing di kancah perekonomian saat ini. Pertemuan para pemimpin negara-negara ASEAN yang sepakat membentuk pasar tunggal di kawasan ASEAN, yang dikenal dengan sebagai Masyarakat Ekonomi ASEAN (MEA). Berlakunya Masyarakat Ekonomi ASEAN merupakan sebuah tantangan dan sekaligus peluang besar yang harus dihadapi masyarakat dan perusahaanperusahaan di Indonesia khususnya dalam menghadapi persaingan global serta meningkatkan perekonomian Indonesia. Hal ini memaksa setiap perusahaan yang ada di Indonesia agar mampu mempertahankan eksistensinya atau bahkan dapat unggul dalam persaingan ditengah arus pasar bebas MEA.

Untuk mampu bertahan dalam persaingan arus pasar bebas MEA, strategi diversifikasi merupakan cara yang dipilih oleh manajer dalam pengembangan bisnisnya. Perusahaan akan menghasilkan produk dan jasa dengan berbagai inovasi yang berbeda jauh dengan produk dan jasa utama perusahaan melalui strategi diversifikasi yang dilakukan. Strategi diversifikasi di negara-negara berkembang menjadi hal yang menarik untuk diteliti. Hal ini disebabkan oleh negara berkembang belum memiliki mekanisme pasar modal eksternal yang maju seperti Indonesia, sehingga proses alokasi modal secara internal melalui diversifikasi menjadi dominan. (Inayah, 2014). Hal ini dapat dilihat dari banyaknya perusahaan yang terdaftar di Bursa Efek Indonesia melakukan strategi ini. Perusahaan yang paling banyak melakukan strategi diversifikasi adalah sektor industri barang konsumsi sebesar $84 \%$. Beberapa contoh perusahaan sub sektor food and beverages yang menerapkan strategi divesifikasi adalah PT Indofood Sukses Makmur Tbk yang merambah bisnis pengolahan makanan berbasis protein hewani, PT Mayora Indah Tbk yang melakukan diversifikasi produk, PT Akasha Wira International 
Tbk melakukan diversifikasi usaha diluar bisnis AMDK seperti produk minuman susu kedelai dan produk makanan, dan PT Siantar Top Tbk melakukan diversifikasi di beberapa product line yaitu biskuit, sereal, kerupuk dan cokelat olahan.

Tujuan penerapan strategi diversifikasi ini adalah perusahaan dapat mempercepat pengembangan usaha, meningkatkan laba perusahaan, menangkap peluang pasar, meningkatkan daya saing dalam industri dan meningkatkan efisiensi pengalokasian sumber daya yang dimiliki oleh perusahaan. Keputusan perusahaan untuk mengimplementasikan strategi diversifikasi sendiri dapat dilihat dan dianalisis melalui dua sudut pandang. Kedua sudut pandang ini adalah Resource Base View dan Market Power Theory (Christiningrum, 2014). Selain itu tujuan perusahaan melakukan strategi diversifikasi dianggap mampu membawa pengaruh positif terhadap peningkatan kinerja keuangan perusahaan dengan cara mempunyai keanekaragaman usaha. Hal ini dikarenakan strategi diversifikasi dapat memperkuat keunggulan bersaing perusahaan jika dibandingkan dengan perusahaan yang hanya melakukan bisnis tunggal dan juga dapat mengurangi risiko jika salah satu bisnisnya mengalami penurunan. Di dalam pendekatan kekuatan pasar, strategi diversifikasi akan memiliki pengaruh positif terhadap kinerja perusahaan.

Banyak perusahaan konglomerasi/ terdiversifikasi mempunyai kinerja keuangan yang baik meski memiliki banyak bidang/jenis usaha. Seperti PT Indofood Sukses Makmur Tbk, PT Mayora Indah Tbk, dan PT Indofood CBP Sukses Makmur merupakan perusahaanperusahaan yang menerapkan strategi diversifikasi. Perusahaan-perusahaan ini memiliki pengaruh yang kuat di mata warga Indonesia, dan mampu mencatatkan laba dengan mengesankan. Hal ini terbukti dengan diraihnya Most Powerful Companies Award (MPCA) 2017 yang diraih perusahaan-perusahaan ini. Salah satu yang menjadi metode dalam menganalisa untuk menentukan MPCA adalah EVA, dimana EVA adalah ukuran nilai tambah ekonomis yang dihasilkan oleh perusahaan sebagai akibat dari aktivitas atau strategi manajemen.

Beberapa penelitian yang membahas mengenai pengaruh strategi diversifikasi terhadap kinerja keuangan adalah Inayah (2014) dengan judul penelitian Pengaruh Strategi Diversifikasi Dan Karakteristik Perusahaan Terhadap Kinerja Keuangan. Hasil dari penelitian ini adalah tidak terdapat perbedaan kinerja perusahaan antara perusahaan yang terdiversifikasi dengan perusahaan yang berada pada segmen tunggal, jumlah segmen usaha dan ukuran perusahaan berpengaruh terhadap kinerja manufaktur di Bursa Efek Indonesia sedangkan variabel-variabel leverage, earnings growth, umur perusahaan, PBV, dan ROA tidak berpengaruh terhadap kinerja perusahaan manufaktur di Bursa Efek Indonesia. Berdasarkan latar belakang di atas, maka peneliti tertarik untuk mengetahui apakah terdapat pengaruh strategi diversifikasi terhadap kinerja perusahaan Sub Sektor Food and Beverages.

Teori yang dipakai dalam penelitian ini meliputi Teori keagenan yang menjelaskan hubungan antara pemilik perusahaan dan manajer perusahaan (Jensen dan Meckling, 1976). Penelitian ini membahas mengenai perusahaan yang merupakan suatu rangkaian kontrak (nexus of contract) antara pemilik perusahaan sebagai penanam modal dan manajemen perusahaan sebagai pengelola perusahaan. Pemilik yang menanamkan modalnya memberikan wewenang kepada manajemen untuk mengelola perusahaan. Dengan adanya pelimpahan wewenang pemilik mengharapkan manajemen dapat menjalankan tugasnya dengan baik dan dapat memberikan keuntungan dari penanaman modal yang diberikan oleh pemilik. Tetapi berdasarkan Agency 
Theory ini manajemen juga mempunyai kepentingan untuk memperoleh bonus yang tinggi dari pemilik dari kinerja yang diberikan. Pada saat ini muncul konflik antara kepentingan pemilik dan agen yang dikenal dengan konflik keagenan.

Konflik keagenan muncul karena adanya perbedaan resiko antara manajemen dan pemilik. Manajemen akan berusaha untuk mengurangi resiko yang diterima dalam mengelola perusahaan. Diversifikasi merupakan salah satu cara yang dilakukan oleh manajemen untuk mengurangi risiko dan strategi ini juga memberika keuntungan bagi manajemen dengan menunjukkan kinerjanya memimpin perusahaan sehingga terbentuk perusahaan baru atau inovasi produk yang baru.

$$
\text { Dengan adanya diversifikasi }
$$

manajemen akan mempunyai pengetahuan yang kompleks dan kehadirannya sangat diperlukan oleh perusahaan (Shleifer dan Vishny, 1989 dalam Inayah, Adi dan Eko, 2014). Manajemen melakukan strategi diversifikasi adalah untuk mengurangi resiko yang akan ditanggung dan memperbesar keuntungan yang diperoleh perusahaan sehingga kinerja perusahaan meningkat yang artinya kinerja manajemen juga baik.

Diversifikasi merupakan salah satu strategi yang dipilih oleh manajemen untuk dapat bersaing dengan perusahaan lain. Tujuan strategi ini digunakan oleh manajemen adalah untuk memperluas usaha dengan cara membangun Strategic Business Unit (SBU) atau anak perusahaan, memperluas lini produk yang ada, memperluas wilayah pemasaran produk, membuka kantor cabang, dan melakukan merger dan akuisisi untuk meningkatkan skala ekonomis perusahaan.

Terdapat 3 alasan suatu perusahaan menerapkan strategi diversifikasi antara lain: Pandangan kekuatan pasar (Market Power Theory) yang menyatakan bahwa strategi diversifikasi dapat meningkatkan pangsa pasar dan mengurangi kompetisi, sehingga berdampak positif terhadap kinerja keuangan; Pandangan Sumber Daya (resource based view) yang menyatakan bahwa strategi diversifikasi dilakukan karena adanya kelebihan sumber daya yang ingin dimanfaatkan; Pandanan Keagenan (Agency View) yang menyatakan bahwa strategi diversifikasi merupakan salah satu alat yang dapat dipergunakan untuk meningkatkan laba.

$$
\text { Menurut Satoto }
$$

diversifikasi merupakan salah satu strategi yang dilakukan perusahaan untuk memperluas usahanya dengan membuka beberapa unit bisnis atau anak perusahaan baru baik dalam lini bisnis yang sama dengan yang sudah ada maupun dalam unit bisnis yang berbeda dengan bisnis inti perusahaan. Diversifikasi menjadi pilihan yang menarik bagi perusahan ketika perusahaan menghadapi persaingan yang sangat ketat dan pertumbuhan pasar yang cepat.

Kinerja perusahaan merupakan gambaran suatu kondisi keuangan dalam perusahaan. Kinerja perusahaan ini dapat dianalisis melalui alat analisis keuangan, sehingga investor maupun perusahaan dapat mengetahui baik buruknya keadaan keuangan perusahaan dan akan mencerminkan prestasi kerja dalam periode tertentu. Selain itu manajemen juga dapat memprediksi kondisi keuangan perusahaan untuk beberapa periode kedepan dan menjadi suatu informasi dalam membuat suatu keputusan. Hal ini menjadi pedoman bagi perusahaan agar dapat mampu menghadap perubahan lingkungan yang ada. Penilaian kinerja keuangan merupakan salah satu cara yang dapat dilakukan oleh manajemen dalam memenuhi kewajiban manajemen untuk mempertanggung jawabkan sumber daya yang telah diberikan oleh para investor.

Dalam penelitian ini kinerja perusahaan diukur dengan menggunakan EVA (Economic Value Added). EVA mengukur pengembalian modal dan biaya modal. Kelebihan konsep EVA adalah sebagai berikut: 
1. EVA bermanfaat sebagai penilai kinerja yang berfokus pada penciptaan nilai (value creation)

2. EVA membuat perusahaan lebih memperhatikan struktur modal

3. EVA dapat digunakan untuk mengidentifikasi kegiatan atau proyek yang memberikan pengembalian lebih tinggi daripada biaya modal.

4. EVA dapat menyebabkan perhatian manajemen sesuai dengan kepentingan pemegang saham seingga manajemen akan berpikir dan bertindak seperti halnya pemegang saham yaitu memilih investasi yang memaksimumkan tingkat pengembalian dan meminimumkan tingkat biaya modal sehigga nilai perusahaan dapat dimaksimumkan.

Diversifikasi adalah bentuk dari strategi korporasi yang bertujuan untuk meningkatkan profitabilitas melalui peningkatan volume penjualan dalam bentuk produk baru atau pasar baru. Diversivikasi dapat terjadi pada level unit perusahaan atau level perusahaan.

Hitt et al. (2011:253) menjelaskan bahwa strategi dversifikasi sebagai penciptaan nilai ketika perusahaan dapat meningkatkan daya saing strategis akibat dari penerapan strategi diversifikasi. Selain itu dengan melakukan strategi diversifikasi, perusahaan dapat mengembangkan kekuatan pasarnya untuk meningkatkan penghasilan.

Menurut David (2011:261), resiko terbesar bergerak dalam satu industri tunggal (strategi bisnis tunggal), jika perusahaan hanya mempunyai satu usaha maka jika usaha tersebut mengalami penurunan kinerja terus menerus maka berakibat fatal, karena perusahaan tidak mempunyai cadangan usaha.

Hal ini sejalan dengan hasil penelitian Yuliani, dkk (2012) menyatakan bahwa pengaruh diversifikasi dapat meningkatkan nilai perusahaan. Hasil penelitian Umrie \& Yuliani (2013) juga mengatakan bahwa pengaruh diversifikasi terhadap nilai perusahaan ditemukan signifikan dan positif.
Hipotesis penelitian ini adalah Strategi Diversifikasi Berpengaruh Terhadap Kinerja Perusahaan.

Beberapa penelitian yang meneliti mengenai penelitian ini antara lain: Menurut Inayah, Adi dan Eko (2014) dengan judul Pengaruh Strategi Diversifikasi dan Karakteristik Perusahaan Terhadap Kinerja Keuangan. Hasil penelitian ini adalah: Tidak terdapat perbedaan kinerja perusahaan antara perusahaan yang terdiversifikasi dengan perusahaan yang berada pada segmen tunggal; Pengujian secara simultan menunjukkan adanya pengaruh antara variabel-variabel jumlah segmen usaha, leverage, pertumbuhan laba, ukuran perusahaan, umur perusahaan, PBV dan ROA terhadap kinerja perusahaan; Pengujian secara parsial menunjukkan bahwa variabel-variabel jumlah segmen usaha, dan ukuran perusahaan berpengaruh terhadap kinerja perusahaan manufaktur di Bursa Efek Indonesia; Pengujian secara parsial juga menunjukkan variabel-variabel leverage, earnings growth, umur perusahaan, PBV, dan ROA tidak berpengaruh terhadap kinerja perusahaan manufaktur di Bursa Efek Indonesia.

Menurut Sinta (2009) dengan judul Pengaruh Strategi Diversifikasi Terhadap Kinerja Perusahaan. Hasil penelitian ini menunjukkan strategi diversifikasi berpengaruh negatif terhadap kinerja perusahaan. Ini berarti bahwa perluasan unit bisnis melalui diversifikasi yang dilakukan oleh perusahaan memperkecil atau memberbikan pengaruh yang tidak menguntungkan bagi kinerja perusahaan. Pengaruh negatif ini mungkin disebabkan karena diversifikasi dilakukan di lingkungan perekonomian yang tidak stabil sehingga kurang mendukung strategi diversifikasi yang dilakukan perusahaan.

Menurut Puspita (2015), dengan judul Peran Kepemilikan Manajerial Dalam Memoderasi Pengaruh Strategi Diversifikasi Terhadap Kinerja 
Perusahaan. Hasil penelitian ini adalah tidak ditemukannya bukti yang signifikan mengenai pengaruh diversifikasi terhadap kinerja perusahaan. Tidak ditemukan pula perbedaan yang signifikan mengenai dampak diversifikasi related dan diversifikasi unrelated terhadap kinerja perusahaan. Serta tidak ditemukan bukti yang signifikan mengenai pengaruh moderasi kepemilikan manajerial terhadap hubungan antara diversifikasi terhadap kinerja perusahaan.

Menurut Maswar (2017), dengan judul Pengaruh Kinerja Keuangan Terhadap Nilai Perusahaan Dengan Good Corporate Governance Sebagai Variabel Pemoderasi. Hasil penelitian ini menunjukkan bahwa: (1) Kinerja keuangan berpengaruh positif signifikan terhadap nilai perusahaan. Dan kepemilikan manajerial merupakan variabel pemoderasi hubungan kinerja keuangan terhadap nilai perusahaan, sedangkan kepemilikan institusional bukan merupakan variabel pemoderasi.

\section{METODE}

Jenis data yang digunakan dalam penelitian ini adalah data sekunder yaitu data yang diambil dari laporan tahunan perusahaan periode 2014 - 2017. Data dalam penelitian ini diambil dari laporan keuangan perusahaan yang terdaftar di BEI, Indonesian Capital Market Directory dan Galeri Investasi Unika Musi Charitas Palembang.

Populasi yang digunakan dalam penelitian ini adalah semua perusahaan yang terdaftar di Bursa Efek Indonesia. Sedangkan pemilihan sampel dalam penelitian ini adalah dengan menggunakan metode purposive sampling dengan kriteria berikut : Perusahaan Food And Beverages yang terdaftar di BEI dari tahun 2014 - 2017; Perusahaan yang melakukan strategi diversifikasi selama 10 tahun terakhir

Metode pengumpulan data yang digunakan dalam penelitian ini adalah menggunakan studi pustaka yaitu suatu cara memperoleh data dengan cara membaca, mempelajari buku-buku yang berhubungan dengan masalah yang dibahas.

Variabel dependen dalam penelitian ini adalah Kinerja Perusahaan. Kinerja perusahaan merupakan gambaran suatu kondisi keuangan dalam perusahaan. Kinerja perusahaan ini dapat dianalisis melalui alat analisis keuangan, sehingga investor maupun perusahaan dapat mengetahui baik buruknya keadaan keuangan perusahaan dan akan mencerminkan prestasi kerja dalam periode tertentu.

Dalam penelitian ini kinerja perusahaan diukur dengan menggunakan EVA (Economic Value Added). EVA mengukur pengembalian modal dan biaya modal.

a. Menghitung NOPAT (Net Operating After Tax)

NOPAT $=$ Laba (Rugi) Usaha - Pajak

b. Menghitung Invested Capital

Invested Capital $=($ Total Hutang + Ekuitas $)$

- Hutang Jangka Pendek
c. Menghitung WACC (Weighted Average Cost Of Capital)
$\mathrm{WACC}=[(\mathrm{D} \times \mathrm{rd})(1-\mathrm{Tax})+(\mathrm{E} \times \mathrm{re})]$

Tahapan dalam menghitung WACC (Weighted Average Cost of Capital) dapat dilakukan dengan menggunakan rumus, sebagai berikut:

1) Menghitung Tingkat Modal (D)

Tingkat Modal (D)

$$
\begin{aligned}
& =\frac{\text { Total Hutang }}{\text { Total Hutang dan Ekuitas }} \times 100 \% \\
& \text { 2) Menghitung Biaya Hutang (Cost of } \\
& \text { Debt) }
\end{aligned}
$$

Cost of Debt (rd)

$=\frac{\text { Beban Bunga }}{\text { Total Hutang Jangka Panjang }} \times 100 \%$

3) Menghitung Tingkat Modal/Ekuitas (E)

Ekuitas $(E)=$ Tingkat Modal/

$\frac{\text { Total Ekuitas }}{\text { Total Hutang dan Ekuitas }} \times 100 \%$

4) Menghitung Biaya Ekuitas (Cost of Equity) 


$$
\begin{aligned}
& \text { Cost of Equity (re) } \\
& =\frac{\text { Laba Bersih Setelah Pajak }}{\text { Total Ekuitas }} \times 100 \%
\end{aligned}
$$

5) Menghitung Tingkat Pajak (Tax)

$$
\text { Tingkat Pajak (Tax) }
$$$$
=\frac{\text { Beban Pajak }}{\text { Laba Bersih Sebelum Pajak }} \times 100 \%
$$

d. Menghitung Capital Charges

Capital Charges $=$ WACC $\mathrm{x}$ Invested Capital

e. Menghitung Economic Value Added (EVA)

$\mathrm{EVA}=$ NOPAT - Capital Charges

EVA:

Dalam EVA, penilaian kinerja keuangan diukur dengan ketentuan:

1) Jika EVA > 0, maka kinerja keuangan perusahaan dapat dikatakan baik, sehingga terjadi proses perubahan nilai ekonomisnya.

2) Jika EVA $=0$, maka kinerja keuangan perusahaan secara ekonomis dalam keadaan impas,

Jika EVA < 0 , maka kinerja keuangan Perusahaan tersebut dikatakan kurang bagus karena laba yang diperoleh tidak memenuhi harapan penyandang dana, sehingga tidak terjadi penambahan nilai ekonomis pada perusahaan.

Diversifikasi merupakan salah satu strategi yang dipilih oleh manajemen untuk dapat bersaing dengan perusahaan lain. Tujuan strategi ini digunakan oleh manajemen adalah untuk memperluas usaha dengan cara membangun Strategic Business Unit (SBU) atau anak perusahaan, memperluas lini produk yang ada, memperluas wilayah pemasaran produk, membuka kantor cabang, dan melakukan merger dan akuisisi untuk meningkatkan skala ekonomis perusahaan.

Tingkat diversifikasi diukur dengan menggunakan Hierschman Herfindah Index (HHI). HHI dihitung dengan jumlah dari kuadrat penjualan masing-masing segmen dibagi dengan kuadrat total penjualan perusahaan dengan rumus sebagai berikut (Harto, 2005):

$\mathrm{HHI}=\mathrm{S}_{1}^{2}+\mathrm{S}_{2}^{2}+\mathrm{S}_{3}^{2}+\ldots \mathrm{S}_{\mathrm{n}}^{2}$

Keterangan :

Segsales : Penjual masing-masing segmen

Sales : Total penjualan
Dimana :

Semakin rendah nilai HHI akan menunjukkan semakin terdiversifikasi.

Persamaan regresi dalam penelitian ini adalah :

$\mathrm{Y}=\mathrm{a}+\mathrm{bX} 1+\mathrm{e}$

Keterangan :

$\mathrm{Y}=$ Kinerja Perusahaan

$\mathrm{X} 1=$ Strategi Diversifikasi

e $\quad=$ Error

Pengujian asumsi klasik bertujuan untuk mengetahui dan menguji kelayakan atas model regresi yang digunakan untuk penelitian ini. Pengujian ini juga dimaksud untuk memastikan bahwa didalam model regresi yang digunakan tidak terdapat masalah asumsi klasik seperti normalitas, autokolerasi, heteroskedastisitas dan multikolnearitas.

Uji Normalitas dilakukan untuk mngetahui data berdistribusi normal atau tidak. Ada 2 cara untuk mendeteksi apakah data berdistribusi normal atau tidak adalah dengan analisis grafik dan uji statistis (Ghozali, 2006). Uji normalitas yang digunakan dalam penelitian ini adalah menggunakan Uji statistik Kolmogrov Smirnov.

Uji autokorelasi bertujuan untuk menguji apakah dalam model regresi linear ada korelasi antara kesalahan pengganggu pada periode $t$ dengan kesalahan pengganggu pada periode $\mathrm{t}-1$.

Jika terjadi korelasi, maka dinamakan ada problem autokorelasi muncul karena observasi yang berurutan sepanjang waktu berkaitan satu sama lainnya. Masalah ini timbul karena residual (kesalahan pengganggu) tidak bebas daru satu observasi ke observasi lainnya. Model regresi yang baik adalah yang bebas dari autokorelasi.

Uji autokorelasi dalam penelitian ini dilakukan dengan uji Durbin-Watson (DW test) yang menggunakan titik kritis yaitu batas bawah (dl) dan batas atas (du). Uji Durbin Watson hanya digunaan untuk autokorelasi tingkat satu (first order autocorrelation) dan mensyaratkan adanya intercept (konstanta) dalam model regresi, 
serta tidak ada lagi variabel di antara variabel bebas.

Uji heterokedastisitas bertujuan menguji apakah dalam model regresi terjadi ketidaksamaan variance dari residual satu pengamatan ke pengamatan yang lain. Jika variance dari residual satu pengamatan ke pengmatan lain tetap, maka disebut Homoskedastisitas dan jika berbeda disebut Heterokedastisistas.

Model regresi yang baik adalah yang Homoskedastisitas atau tidak terjadi Heterokedastisitas. Uji heterokedastisitas bertujuan menguji apakah dalam model regresi terjadi ketidaksamaan variance dari residual satu pengamatan ke pengamatan yang lain. Jika variance dari residual satu pengamatan ke pengmatan lain tetap, maka disebut Homoskedastisitas dan jika berbeda disebut Heterokedastisistas. Model regresi yang baik adalah yang Homoskedastisitas atau tidak terjadi Heterokedastisitas. Pengujian heteroskedastisitas menggunakan Uji Glejser yaitu dilakukan dengan mengregres nilai absolut residual terhadap variabel independen.

Uji Hipotesis menggunakan Uji t. Uji statistik $t$ menunjukkan seberapa jauh pengaruh variabel bebas secara individual dalam menerangkan variabel terkait (Ghozali, 2006). Dasar pengambilan keputusan adalah :

1. Jika t-hitung $<\mathrm{t}$-tabel, maka variabel bebas secara individual tidak berpengaruh terhadap variabel terikat (hipotesis ditolak)

2. Jika t-hitung > t-tabel, maka variabel bebas secara individual berpengaruh terhadap variabel terikat (hipotesis diterima)

Uji t dapat juga dilakukan dengan melihat nilai signifikansi $\mathrm{t}$ masing-masing variabel pada output hasil regresi menggunakan SPSS dengan Significance level $0.05 \quad(a=5 \%)$. Jika sig $>0.05$ maka hipotesis ditolak tetapi jika sig $<0.05$ maka hipotesis diterima.

Uji Kelayakan Model (Uji F) menunjukkan apakah semua variabel bebas (independent) mempunyai hubungan terhadap variabel terikat (dependent). Uji F digunakan untuk melihat kelayakan model penelitian. Uji $\mathrm{F}$ dilakukan dengan melihat nilai sig $F$ pada output hasil regresi menggunakan SPSS dengan sig level 0.05 $(\mathrm{a}=5 \%)$. Jika nilai signifikansi lebih besar dari alfa maka hipotesis ditolak (koefisien regresi ditolak) yang berarti model dalam penelitian ini tidak layak.

Koefisien Determinasi (R2) pada dasarnya mengukur seberapa jauh kemampuan model dalam menerangkan variasi variabel terkait. Nilai $\mathrm{R}^{2}$ berada di antara 0 dan 1 . Nilai $R^{2}$ yang kecil berarti kemampuan variabel-variabel bebas dalam menjelaskan variabel terkait sangat terbatas. Nilai yang mendekati 1 berarti variabelvariabel bebas memberikan hampir semua informasi yang dibutuhkan untuk memprediksi variasi variabel terkait (Ghozali, 2006). Dapat juga dikatakan bahwa $\mathrm{R}^{2}=0$ berarti tidak ada hubungan antara variabel bebas dengan variabel terkait, sedangkan $\mathrm{R}^{2}=1$ menandakan suatu hubungan yang sempurna.

\section{HASIL}

Uji normalitas bertujuan untuk mengetahui apakah data terdistribusi secara normal. Data yang terdistribusi secara normal akan menghasilkan regresi yang baik. Untuk menguji normalitas dilakukan dengan uji Kolmogorov-Smirnov Test dengan tingkat signifikansi sebesar $5 \%$. Artinya kesalahan yang masih dapat ditolelir sebesar 5\% dengan tingkat kepercayaan 95\%. Data dikatakan tidak terdistribusi normal jika signifikansi $<0,05$. Sebaliknya, data dikatakan terdistribusi dengan normal jika signifikansi >0,05.

Tabel 1: Uji Normalitas

\begin{tabular}{ll}
\hline & Unstandarized Residual \\
\hline Asymp. Sig (2-tailed) & 0.238 \\
\hline Sumber: Data sekunder yang diolah, 2018
\end{tabular}

Sumber: Data sekunder yang diolah, 2018

Berdasarkan Tabel diatas, nilai Asymp. Sig (2-tailed) pada pengujian Kolmogorov-Smirnov $>0,05$ yaitu sebesar 
0,238. Dengan demikian, dapat disimpulkan bahwa residual hasil analisis terdistribusi secara normal.

Uji Heteroskedastisitas bertujuan menguji apakah dalam model regresi terjadi ketidaksamaan variance dari residual satu pengamatan ke pengamatan yang lain. Jika variance dari residual satu pengamatan ke pengmatan lain tetap, maka disebut Homoskedastisitas dan jika berbeda disebut Heterokedastisistas. Model regresi yang baik adalah yang Homoskedastisitas atau tidak terjadi Heterokedastisitas. Pengujian heteroskedastisitas menggunakan Uji Glejser yaitu dilakukan dengan mengregres nilai absolut residual terhadap variabel independen.

Tabel 2: Hasil Uji Heteroskedastisitas

\begin{tabular}{llll}
$\begin{array}{l}\text { Nama } \\
\text { Variabel }\end{array}$ & $\mathrm{B}$ & $\mathrm{t}$ & Signifikansi \\
Statistik & \\
\hline Konstanta & 236674632498.388 & 3.444 & .002 \\
\hline HHI & -87676304940.733 & -.822 & .417 \\
\hline
\end{tabular}

Dependent Variable: abs

Sumber: Data sekunder yang diolah, 2018

Hasil Uji Regresi Sederhana menunjukkan setelah melakukan uji asumsi klasik, langkah selanjutnya adalah analisis regresi sederhana. Perhitungan analisis dapat dilihat pada Tabel dibawah ini :

Tabel 3: Hasil Uji Regresi Sederhana

\begin{tabular}{llll}
\hline $\begin{array}{l}\text { Nama } \\
\text { Variabel }\end{array}$ & B & t & Signifikansi \\
\hline Konstanta & 139983742757.173 & 1.210 & .235 \\
\hline HHI & -44687776247.962 & -.249 & .805 \\
\hline
\end{tabular}

Sumber: Data sekunder yang diolah, 2018

Berdasarkan hasil tersebut diperoleh persamaan regresi sebagai berikut.

$\mathrm{Y}=139983742757.173-44687776247.962 \mathrm{HHI}+\mathrm{e}$

Uji F merupakan uji kelayakan model yang perlu dilakukan dalam analisis regresi linear. Uji $F$ digunakan untuk menguji kelayakan model regresi untuk digunakan dalam pengujian hipotesis penelitian.
Tabel 4: Hasil Uji F

\begin{tabular}{llclll}
\hline $\begin{array}{l}\text { Mode } \\
l\end{array}$ & Sum of Squares & $\begin{array}{c}D \\
\text { Rean Square }\end{array}$ & $F$ & $\begin{array}{l}\text { Si } \\
g\end{array}$ \\
\hline $\begin{array}{l}\text { Regre } \\
\text { ssion }\end{array}$ & 347888074222479 & 1 & 34788807422247 & .0 & .8 \\
& 2000000.000 & & 92000000.000 & 6 & $\begin{array}{l}05 \\
\text { b }\end{array}$ \\
\hline Resid & 179546161841896 & 3 & 56108175575592 & & \\
ual & 0300000000.000 & 2 & 510000000.000 & & \\
\hline Total & 179894049916118 & 3 & & & \\
& 5000000000.000 & 3 & & & \\
\hline
\end{tabular}

Sumber: Data sekunder yang diolah, 2018

Berdasarkan pada Tabel di atas tingkat signifikan nilai $\mathrm{F}$ adalah 0.805 . Dapat disimpulkan bahwa model regresi yang digunakan dalam penelitian ini tidak baik.

Uji Koefisien Determinasi $\left(\mathbf{R}^{\mathbf{2}}\right)$ digunakan untuk menentukan proporsi atau persentase total variansi dalam variabel dependen yang diterangkan oleh variabel independen. Penelitian ini menggunakan adjusted $\mathrm{R}^{2}$.

Tabel 5: Hasil Uji Koefisien Determinasi

\begin{tabular}{lllll}
\hline Mode & $R$ & $R$ & Adjuste & Std. Error of the \\
$l$ & & Squar & $d \quad R$ & Estimate \\
& & Square \\
\hline 1 & .044 & .002 & -.029 & $\begin{array}{l}236871643671.4038 \\
4\end{array}$ \\
\hline
\end{tabular}

Sumber: Data sekunder yang diolah, 2018

\section{PEMBAHASAN}

Pada Tabel di atas didapat nilai Adjusted $\mathrm{R}^{2}$ dalam penelitian ini sebesar 0.002 atau $0,2 \%$ Hal ini berarti $0,2 \%$ variansi kinerja keuangan dengan EVA dapat dijelaskan oleh variabel Strategi Diversifikasi. Sedangkan sisanya dipengaruhi oleh faktor lain yang tidak diteliti dalam penelitian ini.

Uji $\mathrm{t}$ digunakan untuk menguji seberapa jauh variabel independen secara individual menjelaskan variabel dependen. Berdasarkan hasil output SPSS, terlihat bahwa variabel strategi diversifikasi memiliki signifikansi sebesar 0.805 dimana signifikansi lebih besar dari 0.05 . Hal ini menunjukkan bahwa variabel strategi diversifikasi tidak berpengaruh terhadap kinerja keuangan, sehingga dapat 
disimpulkan hipotesis ditolak.

Diversifikasi merupakan salah satu strategi yang dipilih oleh manajemen untuk dapat bersaing dengan perusahaan lain. Tujuan strategi ini digunakan oleh manajemen adalah untuk memperluas usaha dengan cara membangun Strategic Business Unit (SBU) atau anak perusahaan, memperluas lini produk yang ada, memperluas wilayah pemasaran produk, membuka kantor cabang, dan melakukan merger dan akuisisi untuk meningkatkan skala ekonomis perusahaan

Berdasarkan hasil pengamatan untuk variabel strategi diversifikasi tidak berpengaruh terhadap kinerja keuangan . Hal ini dilihat dari hasil signifikansi sebesar 0.805 lebih besar dari pada 0.05 sehingga hipotesis di tolak. Hal ini mengindentifikasi bahwa perusahaan yang melakukan strategi diversifikasi dengan cara inovasi produk, ekspansi usaha ataupun pembelian aset baru tidak mempengaruhi kinerja keuangan suatu perusahaan. Hal ini dapat terjadi karena strategi yang diterapkan oleh perusahaan juga harus diimbangi dengan pengelolaan biaya modal yang baik sehingga perusahaan dapat memperoleh keuntungan dari strategi yang dipilih oleh perusahaan. Jika pengelolaan keuangan dan pemilihan strategi yang salah maka dapat menyebabkan penurunan kinerja keuangan dalam perusahaan.

Dalam penelitian ini peneliti hanya menggunakan 4 tahun pengamatan, hal ini juga dapat memberikan dampak bahwa penerapan strategi pada masa awal belum menunjukkan keuntungan yang dapat diperoleh perusahaan karena perusahaan mengeluarkan biaya yang besar dalam menerapkan strategi ini sehingga berdampak kepada kinerja keuangan perusahaan tersebut.

Hasil penelitian ini sejalan dengan penelitian yang dilakukan oleh Satoto (2009). Hasil dalam penelitian ini adalah diversifikasi berpengaruh negatif terhadap kinerja perusahaan. Ini berarti bahwa perluasan unit bisnis melalui diversifikasi yang dilakukan oleh perusahaan memperkecil atau memberikan pengaruh yang tidak menguntungkan bagi kinerja perusahaan. Pengaruh negatif ini mungkin disebabkan karena diversifikasi dilakukan di lingkungan perekonomian yang tidak stabil sehingga kurang mendukung strategi diversifikasi yang dilakukan perusahaan. Selain itu, banyak faktor lain yang kurang mendukung diversifikasi yang dilakukan perusahaan, seperti kemampuan manajerial, kurang efisiennya informasi dan sumber dana, maupun perubahan kondisi yang berlangsung dengan cepat. Sehingga diversifikasi yang seharusnya memperbaiki atau memberikan efek positif bagi kinerja perusahaan selama periode yang stabil berubah dalam arah yang berkebalikan dengan adanya perubahan kondisi yang sangat cepat.

\section{SIMPULAN}

Hasil penelitian ini menemukan bahwa hipotesis yang menyatakan variabel strategi diversifikasi berpengaruh terhadap kinerja keuangan ditolak. Hal ini mengindentifikasi bahwa perusahaan yang melakukan strategi diversifikasi dengan cara inovasi produk, ekspansi usaha ataupun pembelian aset baru tidak mempengaruhi kinerja keuangan suatu perusahaan.

Sebagai saran untuk penelitian selanjutnya diharapkan dapat menambah proksi lain untuk variabel independennya, rentang waktu penelitian berikutnya bisa lebih dari 4 tahun, dan dapat dilakukan pada skope yang lebih luas lagi seperti pada sektor manufaktur.

\section{DAFTAR RUJUKAN}

Hutagalung, Sutan Oloan M. \& Vera Diyanty. 2014. Analisis Pengaruh Strategi Diversifikasi Terhadap Tingkat Penggunaan Utang Perusahaan. Simposium Nasional Akuntansi XVII. Mataram

Heder, Maswar Patuh Priyadi. 2017. Pengaruh Kinerja Keuangan Terhadap Nilai Perusahan Dengan 
Good Corporate Governance Sebagai Variabel Pemoderasi. Jurnal Ilmu dan Riset Akuntansi. Volume 6 No. 7, Juli 2017. ISSN: 2460-0585

Hitt, Michael A., R. Duane Ireland, and Robert E. Hoskisson. 2001. Manajemen Strategis Daya Saing dan Globalisasi. Edisi Pertama. Salemba Empat. Jakarta.

Inayah. 2014. Pengaruh Strategi Diversifikasi Dan Karakteristik Perusahaan Terhadap Kinerja Perusahaan. JAFFA. Vol 2 No, 1. April 2014. Hal 13-22

Jensen, M dan Meckling, W. (1976). Theory of The Firm : Managerial Behavior, Agency Costs and Capital Structure. Journal of Financial Economics, 3(4), $305-360$.

Keiso, D.E.,Weygandt, J.J \& Warfield, T.D. 2007. Intermediate Accounting. New Jersey : John Wiley \& Sons Inc.

Ni Made, I Wayan, Ni Ketut. 2015. Pengaruh Diversitas Pengurus PAda Luas Pengungkapan CSR Perusahaan Sektor Keuangan. E - Jurnal Ekonomi dan Bisnis Universitas Udayana 4.05 (2015) : 312 - 330. ISSN : 2337 - 3067.

Puspita Rani. 2015. Peran Kepemikikan Manajerial Dalam Memoderasi Pengaruh Strategi Diversifikasi Terhadap Kinerja Perusahaan. Jurnal Akuntansi dan Keuangan. Vol 4 No 2 Oktober 2015. ISSN : 22527141

Priyadi, Maswar Patuh. 2017. Pengaruh Kinerja Keuangan terhadap Nilai Perusahaan dengan Good Corporate Governance sebagai Variabel
Pemoderasi, Jurnal Ilmu dan Riset Akuntansi, Vol.6, No.7, Juli 2017

Rahayu, Indu Prasetya Ning \& Abdul Rohman. 2014. Pengaruh Diversifikasi Operasional Terhadap Struktur Modal dengan Kepemilikan Pemerintah sebagai Variabel Moderasi. Diponegoro Journal of Accounting, Vol 3 No 3. Hal 1-14.

Rani, Puspita. 2015. Peran Kepemilikan Manajerial dalam Memoderasi Pengaruh Strategi Diversifikasi terhadap Kinerja Perusahaan, Jurnal Akuntansi dan Keuangan, Vol.4, No.2 Oktober 2015

Rocca, Maurizio La et. all. 2009. The Effect of Diversification on Capital Structure. Accounting \& Finance, Vol 49 No 4. Hal 799-826.

Sari, Inayah Adi.Wiratno, Adi. Dan Suyono, Eko. 2014. Pengaruh Strategi Diversifikasi dan Karakteristik Perusahaan terhadap Kinerja Perusahaan, JAFFA, Vol.2 no.1 April 2014, hal.13-22

Sintha Heru, Satoto. 2009. Strategi Diversifikasi terhadap Kinerja Perusahaan, Jurnal Keuangan dan Perbankan, Vol.13, No.2 Mei 2009, 280-287

Sulastri, Uli. Pengaruh Strategi Diversifikasi terhadap Kinerja Keuangan Perusahaan dengan Struktur Modal sebagai Variabel Intervening; Pada Perusahaan Sektor Properti dan Real Estate di Bursa Efek Indonesia Periode 2009-2013

Wardhani, Ratna \& Ade Sobrina Hasibuan. 2011. The Effect of Related and Unrelated Diversification of Capital Structure Policy: 
Empirical Evidence on Indonesian Companies. Simposium Nasional Akuntansi XIV. Aceh.

Wisnuwardhana, Aryo dan Diyanty, Vera. Pengaruh Strategi Diversifikasi terhadap Kinerja Perusahaan dengan Moderasi Efektifitas Pengawasan Dewan Komisaris, Universitas Indonesia, SNA XVIII Medan, 2015

Rahayu, Indu Prasetya Ning \& Abdul Rohman. 2014. Pengaruh Diversifikasi Operasional Terhadap Struktur Modal dengan Kepemilikan Pemerintah sebagai Variabel Moderasi. Diponegoro Journal of Accounting, Vol 3 No 3. Hal 1-14.

Rocca, Maurizio La et. all. 2009. The Effect of Diversification on Capital Structure. Accounting \& Finance, Vol 49 No 4. Hal 799-826.

Yuliani, Zain, Djumilah, Sudarma, Made, dan Solimun. 2012. "Diversification,Investment Opportunity Set, Envinronmental Dynamics and Firm Value(Empirical Study of Manufacturing Sectors in Indonesia Stock Exchange)". IOSR Journal of Business and Management. ISSN: 2278-487X. Volume 6 